\title{
SLAUGYTOJŲ ŽINIOS APIE TRACHEOSTOMOS VAMZDELIO MANŽETÉS PRIEŽIŪRĄ PRIEŠ IR PO MOKYMO
}

\author{
Silva Kostyliovienè ${ }^{1,4}$, Alina Vaškelytė ${ }^{1,2}$, Dovilè Grinkevičiūte $\dot{e}^{3,4}$ \\ ${ }^{1}$ Kauno kolegijos Medicinos fakulteto Slaugos katedra, ${ }^{2}$ Lietuvos sveikatos mokslu universiteto \\ Medicinos akademijos Slaugos ir rüpybos katedra, ${ }^{3}$ Lietuvos sveikatos mokslu universiteto \\ Medicinos akademijos Medicinos fakulteto Vaiku ligu klinika, \\ ${ }^{4}$ Lietuvos sveikatos mokslu universiteto ligoninès Vaiku intensyviosios terapijos skyrius
}

Raktažodžiai: slaugytojų žinios prieš mokymą, slaugytojų žinios po mokymo, tracheostomos vamzdelio manžetès priežiūra.

\section{Santrauka}

Tracheostomos vamzdelio manžetès priežiūra yra susijusi su didele rizika paciento sveikatai, todèl svarbu, kad slaugytojai turètų mokslo irodymais pagrịstų žinių apie manžetès priežiūrą. Jeigu slaugytojai turès pakankamai žinių ir gerus praktinius igūdžius kokybiškai atlikti šią procedūrą, tai iki minimumo sumažins galimų nepageidaujamų įvykių dažnumą, užtikrins paciento saugumą. Darbo tikslas išanalizuoti slaugytojų žinias apie tracheostomos vamzdelio manžetès priežiūrą prieš ir po mokymo. Tyrimas vyko 2013 m. Kauno miesto ligoninių skyriuose, ị kuriuos tracheostomuoti pacientai dažniausiai patenka iš Intensyviosios terapijos skyrių. Dalyvauti tyrime buvo pakviesti visi 111 tuose skyriuose dirbančiu slaugytojų. Tyrimas buvo vykdomas etapais: 1) slaugytojų anketiné apklausa prieš mokymus; 2) slaugytojų mokymai; 3) slaugytoju apklausa po mokymų. Apklausoje prieš mokymus dalyvavo 93 slaugytojai, po mokymo - 81. Tyrimo duomenims rinkti buvo naudojama autorių sukurta Slaugytojų žinių nustatymo anketa.

Rezultatai. Dauguma apklaustų slaugytojų teigè, jog manžetės slègio specialiu manometru nematuoja (prieš mok. - 95,2 proc., po mok. - 98,3 proc.). Prieš ir po mokymų beveik pusè slaugytojų teigè, kad niekada nepripučia oro $i \mathfrak{i}$ tracheostomos vamzdelio manžetę (prieš mok. - 47,6 proc., po mok. - 45,8 proc.). Po mokymo statistiškai reikšmingai daugiau slaugytojų (44,4 proc.) nurodè, kad orą iš tracheostomos vamzdelio manžetės išleidžia kas tris - keturias val., o prieš mokymą taip darantys nurodẻ tik
20,1 proc. respondentu $\left(\chi^{2}=12,162 ; 11 s=1 ; p=0,007\right)$. Prieš mokymą 60,9 proc. tiriamujų nurode, kad visai neišleidžia oro iš tracheostomos vamzdelio manžetès, o po mokymo taip teigè 40,3 proc. slaugytojų $\left(\chi^{2}=12,162 ; 11 \mathrm{~s}=1 ; \mathrm{p}=0,007\right)$. Po mokymo 50,6 proc. slaugytojų nurodè, kad manžetès slègis turi būti mažesnis nei $20 \mathrm{cmH} 2 \mathrm{O}$, nors prieš mokymą toki slègi nurode 3,6 proc. respondentų $\left(\chi^{2}=59,048 ; 11 s=3\right.$; $\mathrm{p}<0,001)$. Po mokymo 21,0 proc. tiriamujų manè, kad nesvarbu, koks slègis tracheostomos vamzdelyje, svarbu kad būtų daug išpūsta, o prieš mokymą taip teigè 65,5 proc. apklausoje dalyvavusių slaugytojų $\left(\chi^{2}=59,048 ; 1 l s=3 ; p<0,001\right)$. Didžioji dalis (79,6 proc.) slaugytojų, kurie išsimokslinimą igijo medicinos mokykloje, po mokymo teigè, kad prieš išleidžiant orą iš tracheostomos vamzdelio manžetès išsiurbia sekretą iš burnos ir nosiaryklès, nors prieš mokymą taip teigè darantys 51,7 proc. respon$\operatorname{dentų~}\left(\chi^{2}=9,007 ; 11 s=1 ; p=0,003\right)$.

Išvados. Po mokymo reikšmingai didesnè dalis slaugytojų teisingai nurodè, kad orą iš tracheostomos vamzdelio manžetès išleidžia kas tris - keturias val.; o manžetès slègis turi būti ne mažesnis nei $20 \mathrm{cmH} 2 \mathrm{O}$. Reikšmingai didesnè dalis slaugytojų, kurie išsimokslinimą igijo medicinos mokykloje, po mokymo teigè, kad prieš išleidžiant orą iš tracheostomos vamzdelio manžetės išsiurbia sekretą iš burnos ir nosiaryklès. Prieš ir po mokymų dauguma apklaustujų teigè, jog manžetės slègio specialiu manometru nematuoja, o oro ị vamzdelio manžetę pagal manometro rodiklius pripučia tik nedidelè dalis slaugytojų.

\section{Ivadas}

Tracheostomija - viena seniausiai atliekamų chirurginių operacijų, kurios metu atveriama tracheja kvépavimo 
takų praeinamumui užtikrinti [1]. Vienas iš seniausių įrašų apie tracheostomiją galima laikyti Rig Vedoje, senovès indų medicinos knygoje, aprašytą pasveikimo atveji perpjovus gerklę, datuotą bronziniame amžiuje 2000 metu prieš mūsų erą (prieš m. e.) [2].

Lietuvoje tik nuo $2010 \mathrm{~m}$. pradètas bendras tracheostomuotu pacientu registras, bet duomenu apie tracheostomuotų pacientų skaičių Lietuvoje gauti nepavyko. Nuo $2010 \mathrm{~m}$. pradètas nepageidaujamų ịvykių registras, bet atskiro registro nepageidaujamų ịvykių, susijusių su tracheostoma, nèra [3].

Tracheostomai naudojami vamzdeliai gali būti su manžetėmis ir be jų. Manžetè, t. y. balionèlis vamzdelio išorèje, reikalinga siekiant išvengti burnos sekreto ar skrandžio turinio ịtekejjimo ị kvèpavimo takus, taip pat siekiant užsandarinti kvėpavimo takus. Tracheostomos vamzdelis neužima viso trachèjos spindžio, tik išpūsta manžetė priglunda prie trachèjos sienelès. Trachèjos kapiliarų perfuzinis slègis paprastai yra nuo $25 \mathrm{iki} 35 \mathrm{cmH}_{2} \mathrm{O}$ [4]. Manžetès slègio poveikio tyrimo metu nustatyta, kad patologinių pokyčiu pobūdis trachejos sienoje priklauso nuo intubacijos laiko ir manžetès spaudimo ị trachejos sieną [5]. Spaudimui neviršijant $20 \mathrm{~mm} \mathrm{Hg}$ stulpelio, jau po $15 \mathrm{~min}$. atsiranda paviršiniai, bet toliau neprogresuojantys gleivinès pokyčiai. Spaudimui padidejus iki $50 \mathrm{~mm} \mathrm{Hg}$ stulpelio, per $15 \mathrm{~min}$. atsiranda nepadengti epitelio ląstelèmis bazinès membranos plotai. Jei slègis manžetėje neviršija $20 \mathrm{~mm} \mathrm{Hg}$ stulpelio net ir ilgai laikant vamzdeli, negrįžtami patologiniai pokyčiai nesusidaro [5].

Manžetės slėgio valdymas yra svarbus aspektas stengiantis išvengti komplikacijų. Jeigu slègis manžetejje per mažas, manžetė neatlieka savo funkcijos - neužsandarina kvėpavimo takų ir neapsaugo nuo burnos sekreto ar skrandžio turinio įtekèjimo ị kvėpavimo takus. Jeigu slègis manžetėje per didelis, ji spaudžia trachèjos sienelę, toje vietoje pablogeja kraujotaka, ir gali pradèti vystytis komplikacijos: trachejjos gleivinès išemija ar trachejjos stenozė [6]. Todèl labai svarbu užtikrinti saugų manžetès slègi, kad būtų išvengta komplikacijų. Rekomenduojama tracheostomos vamzdelio manžetėje slègi palaikyti $15-25 \mathrm{cmH}_{2} \mathrm{O}$ [6-10].

Išpūsti ir užpildyti tracheostomos vamzdelio manžetę galima oru. Yra tracheostomos vamzdelių, kurių manžetės, atsižvelgiant ị gamintojo rekomendacijas, gali būti užpildomos skysčiu [11]. Tai atliekama naudojant švirkštą ar specialų manometrą. Atlikti tyrimai rodo, kad išpučiant manžetę švirkštu, o slègi nustatant čiuopant pirštais balionèlį, tik trečdalyje atvejų manžetès slègis buvo rekomenduojamos normos ribose [12]. Todèl manžetès slègị rekomenduojama matuoti specialiu manometru $[10,12,13]$. Plotnikow G.A., Roux N., Feld W. ir kt. (2013) rekomenduoja manžetès slè- gio matavimus spontaniškai kvejpuojantiems pacientams atlikti dažniau nei kas keturias val. [13]. Kai kurie autoriai nurodo, kad pacientų saugumui užtikrinti būtų galima manžetės slègi monitoruoti ir stebèti pastoviai specialaus prietaiso pagalba [14], tačiau nepavyko rasti duomenų, kad Lietuvoje manžetès slègis būtų monitoruojamas ir stebimas nuolat. Todèl rekomendacijose nurodoma, kad manžetès slègi būtina tikrinti kas 4 - 8 val. [15]. Belgijoje (2014) atlikto tyrimo rezultatai atskleide, kad keičiant paciento kūno padètí, keičiasi ir endotrachejjinio vamzdelio slègis [16]. Japonijoje (2014) buvo nustatyta, kad 45 proc. atveju manžetès slègis per 2 val sumažèjo nuo 24 iki $20 \mathrm{cmH} 2 \mathrm{O}$, todèl rekomenduojama matuoti ir koreguoti manžetės slègị kas 2 val. [17]. Kiti autoriai nurodo, kad mažetės slègi rekomenduojama stebèti reguliariai, nors vieną kartą per darbo pamainą ir patikrinti po atliktų procedūrų $[7,9,11]$.

Kadangi manžetė priglunda prie trachẻjos sienelès, toje vietoje gali sutrikti trachejos sienelès kraujotaka. Rekomenduojama kas $4-8$ val. iš manžetès visiškai išleisti orą, tačiau tai sukelia galimybę burnos ar skrandžio turiniui ittekèti i kvépavimo takus ir didina ventiliacinès pneumonijos riziką. Prancūzijos mokslininkų $2010 \mathrm{~m}$. atlikto tyrimo metu irrodyta, kad subglotinis siurbimas labai sumažina ventiliacinès pneumonijos dažnumą [18]. Kad būtų galima išvengti burnos ar skrandžio turinio ịtekejjimo ị kvèpavimo takus, prieš atleidžiant manžetę rekomenduojama išsiurbti sekretą iš burnos ir nosiaryklès $[7,9,15,18]$.

Tracheostomos vamzdelio manžetès priežiūra yra susijusi su didele rizika paciento sveikatai, todèl svarbu, kad slaugytojai turètų mokslo ịrodymais pagrịstų žinių apie manžetès priežiūrą. Jeigu slaugytojai turès pakankamai žinių ir gerus praktinius igūdžius kokybiškai atlikti šią procedūrą, tai iki minimumo sumažins galimų nepageidaujamų ìvykių dažnumą, užtikrins paciento saugumą.

Darbo tikslas: išanalizuoti slaugytojų žinias apie tracheostomos vamzdelio manžetès priežiūrą prieš ir po mokymo.

\section{Tyrimo medžiaga ir metodai}

Tyrimas vyko $2013 \mathrm{~m}$. Kauno miesto ligoninių skyriuose, i kuriuos tracheostomuoti pacientai dažniausiai patenka iš Intensyviosios terapijos skyrių (ITS). Dalyvauti tyrime buvo pakviesti visi 111 tuose skyriuose dirbančių slaugytojų. Tyrimas buvo vykdomas etapais: 1) slaugytojų anketiné apklausa prieš mokymus; 2) slaugytojų mokymai; 3) slaugytojų apklausa po mokymų.

Anketine apklausa prieš mokymus buvo siekiama nustatyti slaugytojų žinias apie tracheostomos priežiūrą, išsiaiškinti, ko trūksta ir kas galètų pagerinti tracheostomos priežiūrą. Apklausoje sutiko dalyvauti ir buvo išdalintos 93 
anketos, iš kurių grịžo ir tinkamos analizei buvo 84, atsako dažnis - 96,77 proc.

Po anoniminès anketinès apklausos buvo atliekamas mokymas: dviejų akademinių val. trukmès paskaita ir seminaras „Mokslo ịrodymais pagrista tracheostomos priežiūra“. Vèliau vykdavo aktyvios diskusijos su slaugytojais.

Anketine apklausa po mokymų buvo siekiama nustatyti, kiek yra efektyvus mokymas ir kaip keitèsi slaugytojų žinios. Apklausa buvo vykdoma praejus penkeriems mènesiams po mokymų. Antrosios anketinès apklausos metu po mokymų buvo išdalintos 93 , grižo 86 anketos. Penkios anketos nebuvo iki galo užpildytos, analizei naudota 81 anketa. Atsako dažnis - 92,47 proc.

Pagal amžių 9,5 proc. respondentų priklausè jaunesnių nei $29 \mathrm{~m}$. grupei; $30-39 \mathrm{~m}$. amžiaus grupei priklausè 21,4 proc.; $40-49$ m. amžiaus grupei - 38,1 proc. ir vyresnių nei 50 m. - 31,0 proc. tiriamujų. Daugiau nei pusè (69,0 proc.) respondentų išsimokslinimą igijo medicinos mokyklose; beveik penktadalis (17,8 proc.) turejo aukštaji neuniversitetinị ir dešimtadalis (11 proc.) aukštajị universitetinį išsimokslinimą. Didžioji dalis respondentų ( 76,2 proc.) turejjo daugiau nei dešimties metų, 10,7 proc. - nuo šešerių iki dešimties ir 13,1 proc. - mažiau nei penkerių metų klinikinio darbo patirtị.

Tyrimas atliktas naudojant autorių sukurtą Slaugytojų žinių nustatymo anketą. Buvo atliktas anketos išorinio patikimumo vertinimas taikant testo-testo (test-retest) metodą. Dešimt slaugytojų atsake į anketos klausimus pirmą kartą ir tyrimas buvo pakartotas po septynių dienų su tais pačiais slaugytojais.

Kokybiniams dydžiams analizuoti buvo taikomas McNemar testas. Tik keturiuose galimuose atsakymų variantuose buvo paklaida $(\mathrm{p}>0,05)$, visi kiti klausimai ir atsakymai visiškai sutapo. Koreliacinè analizè atlikta taikant testo-testą, siekiant nustatyti statistinius ryšius tarp pirmosios ir antrosios apklausos ranginių ar kiekybinių dydžių. Taikant Spearmen'o koreliacijos koeficientą, tik 12 klausimų po vieną iš galimų atsakymo varianatų buvo $r<0,7$, likusiuose klausimuose ir atsakymuose $r>0,7$. Visi klausimų atsakymai buvo patikslinti prieš atliekant tyrimą. Slaugytojų žinių nustatymo anketa buvo naudojama vertinant slaugytojų žinias prieš ir po mokymo.

Rezultatų analizei ir duomenu pateikimui buvo naudota aprašomosios statistikos skaitinès charakteristikos: vidurkis, standartinis nuokrypis, pasiskirstymas dažniais pateikiamas procentine išraiška. Esant nenormaliam pasiskirstymui, tarp dviejų grupių, buvo taikomas Mann - Whitney testas, o esant daugiau nei dviem grupems - Kruskal - Wallis testas. Esant normaliam pasiskirstymui tarp dviejų grupių, buvo taikomas T testas arba Stjudent'o testas, kai grupių buvo daugiau nei dvi - ANOVA testas. Kokybinių požymių statistinis ryšys buvo tiriamas susietų lentelių metodu. Remiantis lentelių duomenimis, apskaičiuota chi kvadrato $\left(\chi^{2}\right)$ reikšmè, laisvès laipsnių skaičius (lls), rezultatai laikyti statistiškai patikimais, kai statistinio reikšmingumo koeficientas $\mathrm{p}<0,05$.

Tyrimui atlikti buvo gautas LSMU Bioetikos centro pritarimas Nr. BEC-KS (M)-198.

\section{Rezultatai}

Siekiant sužinoti, ar slaugytojai tracheostomos vamzdelio manžetès slègi matuoja su specialiu manometru, rezultatai atskleidè, kad dauguma apklaustų slaugytojų teigé, jog manžetès slègio specialiu manometru nematuoja (prieš mok. - 95,2 proc., po mok. - 98,3 proc.; $\mathrm{p}>0,05$ ).

Prieš ir po mokymų beveik pusè slaugytojų teigè, kad niekada nepripučia oro ị tracheostomos vamzdelio manžetę (prieš mok. - 47,6 proc., po mok. - 45,8 proc.; $\mathrm{p}>0,05$ ), apie penktadalis oro pripučia tiek, kad pilnai išsipūstų manžetė (prieš mok. - 27,4 proc., po mok. - 26,4 proc.; $\mathrm{p}>0,05$ ), nedidele dalis - pagal manometro duomenis (prieš mok. - 14,3 proc., po mok. - 26,4 proc.; p>0,05), labai maža dalis - 10 ml. (prieš mok. - 7,1 proc., po mok. - 1,4 proc.; $p>0,05$ ) ir 20 ml. (prieš mok. - 3,6 proc., po mok. - 0 proc.; $p>0,05$ ) oro.

Po mokymo statistiškai reikšmingai daugiau slaugytojų $(44,4$ proc.) nurodè, kad orą iš tracheostomos vamzdelio manžetės išleidžia kas tris - keturias val., o prieš mokymą taip darantys nurode tik penktadalis $(20,1$ proc.) respondentų $\left(\chi^{2}=12,162 ; 11 s=1 ; p=0,007\right)$. Pirmosios apklausos metu prieš mokymą didesnè dalis slaugytojų (60,9 proc.) nurodè, kad visai neišleidžia oro iš tracheostomos vamzdelio manžetès, o po mokymo taip teigè tik mažiau nei pusé $\left(40,3\right.$ proc.) slaugytojų $\left(\chi^{2}=12,162 ; 1 l s=1 ; p=0,007\right)$. Šiek tiek daugiau nei dešimtadalis respondentu nurodè orą iš tracheostomos vamzdelio išleidžiantys kas keturias - šešias val. (prieš mok. - 14,3 proc., po mok. - 15,3 proc.; p>0,05), labai maža dalis -vieną kartą paroje (prieš mok.- 3,6 proc., po mok.- 0 proc.; $\mathrm{p}>0,05$ ).

Reikšmingai didesnè dalis slaugytojų ( 69,0 proc.), išsimokslinimą ịgijusių medicinos mokykloje, prieš mokymą nurode, kad visai neišleidžia oro iš tracheostomos vamzdelio manžetès, tik apie penktadalis (17,2 proc.) nurodè orą iš tracheostomos vamzdelio manžetės išleidžiantys kas tris - keturias val., tuo tarpu po mokymo - visai neišleidžiantys oro nurodè tik mažiau nei pusè (40,8 proc.), kas tris - keturias val. - apie pusę ( 46,9 proc.) slaugytojų $\left(\chi^{2}=13,124\right.$; $11 \mathrm{~s}=1 ; \mathrm{p}=0,004)$.

Daugiau nei pusė $(54,5$ proc.) slaugytojų, turinčiu 5 metų ir mažiau darbo patirties, nurode išleidžiantys orą iš 
manžetės kas tris - keturias val., tuo tarpu taip darantys teigė maža dalis slaugytojų, turinčių šešerių-dešimties metų (11,1 proc.) bei dešimt metų ir daugiau darbo patirti (17,2 proc.) $\left(\chi^{2}=17,449 ; 11 s=6 ; p=0,008\right)$.

Didžioji dalis $(79,6$ proc.) slaugytojų, kurie išsimokslinimą įgijo medicinos mokykloje, po mokymo teigè, kad prieš išleidžiant orą iš tracheosto-

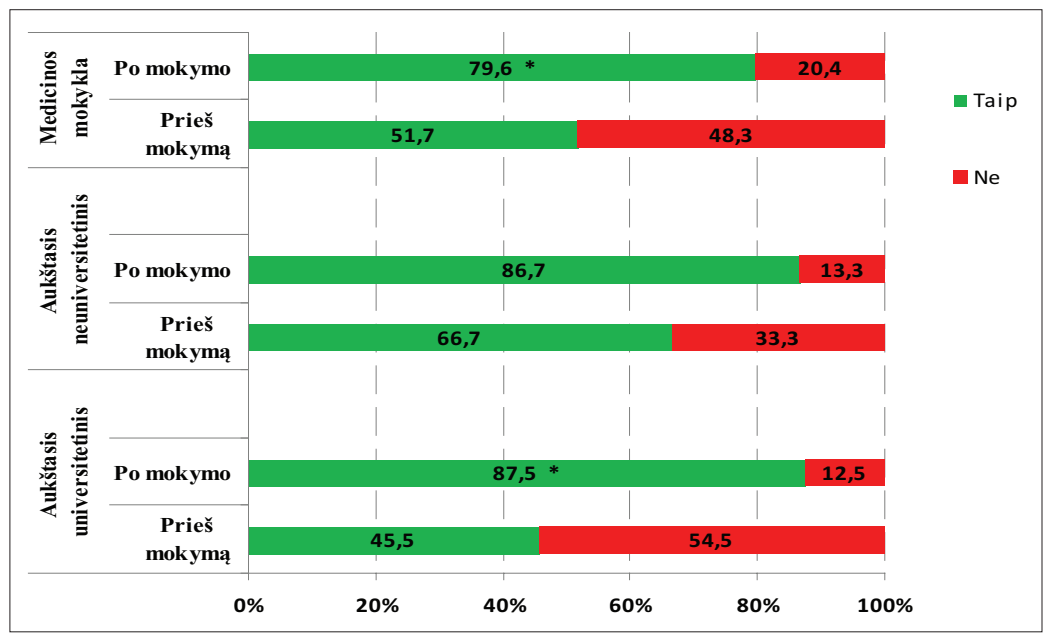

1 pav. Slaugytojų žinios apie sekreto siurbimą iš burnos ir nosiaryklès prieš siurbiant iš tracheostomos vamzdelio, atsižvelgiant ị išsimokslinimą $* p<0,05$ lyginant su rezultatais prieš mokyma

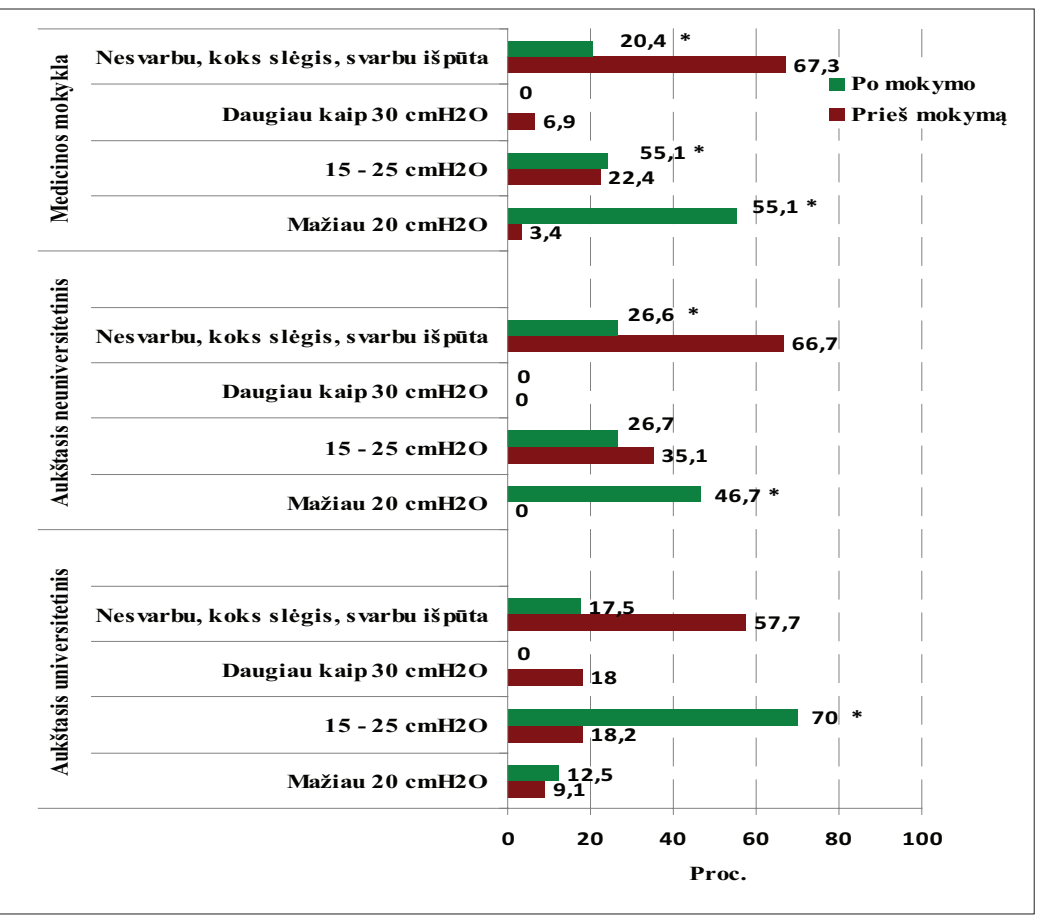

2 pav. Slaugytojų žinios apie tracheostomos vamzdelio manžetès slègị, atsižvelgiant į išsimokslinimą

${ }^{*} p<0,05$ lyginant su rezultatais prieš mokyma mos vamzdelio manžetès išsiurbia sekretą iš burnos ir nosiaryklès, nors prieš mokymą taip teigè darantys tik apie pusè $(51,7$ proc.) slaugytojų $\left(\chi^{2}=9,007 ; 11 s=1 ; p=0,003\right) \quad(1$ pav.).

Abiejų anketinių apklausu metu apie penktadalis slaugytojų nurodè, kad manžetès slègis turi būti $15-25 \mathrm{cmH} 2 \mathrm{O}$ (prieš mok. - 23,6 proc., po mok. - 28,4 proc.; $\mathrm{p}>0,05)$. Tačiau po mokymo apie pusè (50,6 proc.) slaugytojų nurodè, kad manžetès slègis turi būti mažesnis nei $20 \mathrm{cmH} 2 \mathrm{O}$, nors prieš mokymą tokị slègị nurodẻ nedidelè dalis $\left(3,6\right.$ proc.) slaugytojų $\left(\chi^{2}=59,048\right.$; $11 s=3 ; p<0,001)$. Po mokymo tik apie penktadalis (21,0 proc.) slaugytojų nurode, kad nesvarbu, koks slègis tracheostomos vamzdelyje, svarbu kad būtu daug išpūsta, o prieš mokymą taip teige daugiau nei pusé (65,5 proc.) apklausoje dalyvavusių slaugytojų $\left(\chi^{2}=59,048 ; 11 s=3 ; p<0,001\right)$.

Analizuojant slaugytojų žinias atsižvelgiant ị jų turimą išsimokslinimą buvo nustatyta, kad: du trečdaliai (67,2 proc.) slaugytojų, kurie išsimokslinimą igijo medicinos mokykloje, prieš mokymą nurodè, jog nesvarbu, koks slëgis manžetėje, svarbu, kad stipriai būtų išpūsta; mažiau nei dešimtadalis $(6,9$ proc.) nurode manžetés slègi mažesnį nei $20 \mathrm{cmH}_{2} \mathrm{O}$., tačiau po mokymo tik penktadalis $(20,4$ proc.) respondentų nurodè, jog nesvarbu, koks slègis ir dauguma (93,1 proc.) nurodè mažesni nei $20 \mathrm{cmH}_{2} \mathrm{O}$ manžetès slègi $\left(\chi^{2}=42,297 ; 11 s=3 ; p<0,001\right)$. Prieš mokymus nè vienas ( 0 proc.) slaugytojas, turintis aukštaji neuniversitetinį išsimokslinimą, nenurodè mažesnio nei $20 \mathrm{~cm}$ $\mathrm{H}_{2} \mathrm{O}$ slègio, o po mokymų tokị slègi nurodè apie pusè slaugytojų ( 46,8 proc.) $\left(\chi^{2}=9,683\right.$; $11 \mathrm{~s}=2 ; \mathrm{p}=0,008)(2$ pav.).

Po mokymo daugiau nei pusè (60 proc.) slaugytojų, turinčių nuo šešerių iki dešimties metų darbo patirtị, nurodè, kad tracheostomos vamzdelio manžetès slègis turi būti mažesnis nei $20 \mathrm{cmH}_{2} \mathrm{O}$, nors prieš mokymą tokio slègio nebuvo nurodęs né vienas ( 0 proc.) respondentas $\left(\chi^{2}=9,493 ; 11 s=3 ; p=0,014\right)$. Po mokymo apie pusè (51,8 proc.) slaugytojų, turinčių dešimties metų ir didesnę darbo patir- 
tị, nurodè, kad tracheostomos vamzdelio manžetès slègis turi būti mažesnis nei $20 \mathrm{cmH}_{2} \mathrm{O}$, tuo tarpu prieš mokymą tokị slègị buvo nurodę tik labai nedidelè dalis $(3,1$ proc.) $\left(\chi^{2}=48,898 ; 11 s=3 ; p<0,001\right)$ tiriamujų.

\section{Diskusija}

Tyrimo metu siekėme išsiaiškinti, kokios yra slaugytojų žinios apie tracheostomos vamzdelio manžetès priežiūrą, ar jos atitinka moksliniais tyrimais pagrịstas rekomendacijas, kokia mokymo reikšmè pagerinant slaugytojų žinias. Analizuojant anketinès apklausos duomenis buvo nustatyta, kad po mokymo reikšmingai pagerėjo slaugytojų, kurie išsimokslinimą ịgijo medicinos mokykloje ir turinčiu didesnę nei dešimt metų darbo patirti, žinios, lyginant su kitomis grupèmis. Po mokymų slaugytojai reikšmingai dažniau teisingai nurode tracheostomos manžetès slègi 15-25 $\mathrm{cm} \mathrm{H}_{2} \mathrm{O}$ ir oro išleidimo iš manžetès laiką, kuris turi būti kas 3-4 val.

Jordan P., Van Rooyen D. ir Venter D. (2012) atlikto tyrimo metu tik 52 proc slaugytojų nurode, kad atliktų manžetės slègio matavimus kas 6 - 12 valandų; 32 procc. - kas 2 - 4 valandas [19].

Stewart SL (2003) [10] (Anglijos Intensyviosios terapijos draugija, (Intensive Care Society) (2008) [7], Morris LL (2013) [8] nurodo maksimalų priimtiną tracheostomos vamzdelio manžetès slègị $18-25 \mathrm{cmH}_{2} \mathrm{O}[7,8,10]$. Hes RD (2014) teigimu, didžiausias manžetès slègis turi būti ne daugiau $30 \mathrm{~cm}$ vandens stulpelio slègio [4].

Pietų Afrikos Respublikoje (PAR) atlikto tyrimo metu (2012) tik 22 proc. slaugytojų nurodè, kad sleggis tracheostomos vamzdelio manžetèje turètų būti $18-22 \mathrm{mmHg}$ [19]. Kito tyrimo (2015) metu apie trečdalis Intensyvios terapijos slaugytojų nurodė palaikantys slègi manžetėje $25 \mathrm{mmHg}$ (36 proc.) ir $30 \mathrm{mmHg}$ ( 32 proc) [24]. Mūsu tyrimo metu slaugytojų grupeje, kurie turejo universitetini išsimokslinimą, po mokymo reikšmingai didesnè dalis nurodè tracheostomos manžetès slègị $15-25 \mathrm{cmH}_{2} \mathrm{O}$. Atliktų tyrimų rezultatai teigia, kad mažas endotrachèjinio vamzdelio manžetès slègis $(<15 \mathrm{mmHg})$ didina mikroaspiracijos ir ventiliacinès pneumonijos riziką $[6,9,11,18]$, didelis endotrachèjinio vamzdelio slègis $(>30-35 \mathrm{mmHg})$ - didina trachejjos sienelès pažeidimo riziką [6].

Nseir S. ir kt. (2009) atliko tyrimą, kurio metu buvo analizuojami 101 pacientų aštuonių šimtų aštuonių valandų manžetès slègio įrašai. Tik 18 proc. pacientu tyrimo metu manžetès slègio įrašymo laiku visą stebejjimo laiką (100. proc) manžetès slégis buvo normalus (20 $-30 \mathrm{cmH}_{2} \mathrm{O}$ ), o likusiems manžetė arba subliūkšdavo, arba būdavo perpučiama [20]. Jaber S. (2007) šešiolikoje ITS atlikto tyrimo metu daugeliu atvejų manžetès slè- gis buvo gerokai didesnis už rekomenduojamą slègi [21].

Siekiant išvengti sekreto, esančio virš tracheostomos vamzdelio manžetès, ịtekejjimo ị apatinius kvejpavimo takus, rekomenduojama prieš sekreto siurbimą iš tracheostomos vamzdelio išsiurbti sekretą iš burnos ir nosiaryklès $[7,9,11,15,18]$. Brazilijoje (2009) atlikto tyrimo metu po mokymų statistiškai reikšmingai daugiau tyrime dalyvavusių sveikatos priežiūros specialistų rinkosi tinkamą sekreto siurbimo seką: burna, nosis, tracheostomos vamzdelis [22]. Mūsu atlikto tyrimo metu po mokymo nebuvo nustatyta statistiškai reikšmingų pokyčių lyginant slaugytojų žinias apie sekreto išsiurbimo seką. Dauguma slaugytojų nurodè, kad tai atlieka priešinga seka: pirmiausia sekretą siurbia iš tracheostomos vamzdelio, po to iš burnos ir nosies.

Australijoje ir Naujojoje Zelandijoje Intensyviosios terapijos skyriuose atliktame tyrime (2008) dauguma (71,0 proc.) slaugytojų nurodè matuojantys manžetės slègị vieną kartą per pamainą ir tik apie penktadalis (22 poc.) slaugytojų slègio patikrinimui naudoja specialų manometrą [23]. Kito tyrimo (2015) rezultatai atskleide, kad dauguma (76 proc.) ITS slaugytojų vamzdelio manžetės slègi matuoja manometru [24]. Mūsų tyrimo metu po mokymo statistišk kai reikšmingai daugiau slaugytojų (44,4 proc.) nurodè, kad orą iš tracheostomos vamzdelio manžetès išleidžia kas tris - keturias val., o prieš mokymą taip darantys nurode tik penktadalis $(20,1$ proc.) respondentų, ir maždaug apie trečdalis slaugytojų nurode, kad manžetės išpūtimui naudotų specialų manometrą.

Šio tyrimo rezultatai buvo iš dalies panašūs ị kitų mokslininkų atliktų tyrimų rezultatus, kurie atskleide, kad slaugytojų žinios ne visada atitinka mokslines rekomendacijas $[19,22,23]$. Kai kurie rezultatai gali skirtis, kadangi dauguma tyrimų atlikti ITS [19,22-24], o mes tyreme slaugytojų, dirbančių ne ITS, žinias. Tyrimai taip pat atskleidè, kad trūksta ịrodymais pagristų rekomendacijų apie tracheostomos vamzdelio priežiūrą praktikoje [19]. Mūsų šalyje nèra vieningo tracheostomos priežiūros standarto, kiekviena gydymo istaiga turi savo priimtas ir patvirtintas metodikas ar darbo instrukcijas, todèl slaugytojai tracheostomos vamzdelio manžetès priežiūrą atlieka atsižvelgiant ị ịstaigos patvirtintas darbines instrukcijas ar i darbo vietoje egzistuojančią praktiką, kuri ne visada atitinka mokslo įrodymais paremtas rekomendacijas. Klinikineje praktikoje, atliekant tracheostomos manžetès priežiūrą, remiantis mokslo įrodymais pagrịstomis rekomendacijomis apie manžetès slègio valdymą, sumažinus atotrūkị tarp žinių ir ịūdžių, galima užtikrinti saugią paciento priežiūrą bei sumažinti komplikacijų skaičių [19]. Manome, kad reikètų detalesnių tyrimų apie slaugytojų žinias atliekant tracheostomos manžetès priežiūrą bei jų pritaikymą klinikinėje praktikoje bei stan- 
dartizuotų tracheostomos priežiūros gairių.

Mūsų atlikto tyrimo rezultatai parodè, kad po mokymo ne visais tracheostomos vamzdelio manžetès priežiūros aspektais pagerèjo slaugytojų žinios. Tai patvirtina ir Day T., Iles N., Griffiths P. (2009) atlikto tyrimo rezultatai, kad tradicinis mokymas gali sukelti tik trumpalaikį žinių pagerejjimą ir nebūtinai lems žinių pritaikymą praktikoje [25].

\section{Išvados}

1. Po mokymo reikšmingai didesnè dalis slaugytojų teisingai nurodé, kad orą iš tracheostomos vamzdelio manžetės išleidžia kas tris - keturias val.; o manžetès slègis turi būti ne mažesnis nei $20 \mathrm{cmH} 2 \mathrm{O}$.

2. Reikšmingai didesnè dalis slaugytojų, kurie išsimokslinimą ịgijo medicinos mokykloje, po mokymo teigè, kad prieš išleidžiant orą iš tracheostomos vamzdelio manžetès išsiurbia sekretą iš burnos ir nosiaryklès.

3. Prieš ir po mokymų dauguma apklaustujų teigè, jog manžetės slègio specialiu manometru nematuoja, o oro ị vamzdelio manžetę pagal manometro duomenis pripučia tik nedidelè dalis slaugytojų.

\section{Literatūra}

1. Durbin CG. Tracheostomy: Why, when, and how? Respir Care 2010;55 (8): 1056-68.

2. Pratt LW, Ferlito A, Rinaldo A. Tracheotomy: historical review. Laryngoscope 2008; 118(9):1597-606.

http://dx.doi.org/10.1097/MLG.0b013e3181783a4c

3. Lietuvos Respublikos sveikatos apsaugos ministro įsakymas "Dèl privalomų registruoti nepageidaujamų įvykių sąrašo ir jų registravimo tvarkos aprašo patvirtinimo, 2010 m. gegužès 6 d. įsakymas Nr. V-401 Valstybès žinios, 2010; 55-2703.

4. Hess DR, Altobelli NP. Tracheostomy tubes. Respir Care 2014;59(6):956-71.

http://dx.doi.org/10.4187/respcare.02920

5. Nordin U. The trachea and cuff-induced tracheal injury. An experimental study on causative factors and prevention. Acta Otolaryngol Suppl 1977;345:1-71.

6. De Lyn P, Bedert L, Delcroix M. et al. Tracheotomy: clinical review and guidelines. European Journal of Cardio-thoracic Surgery 2007;32:412-421.

http://dx.doi.org/10.1016/j.ejcts.2007.05.018

7. Intensive Care Society.Standards for the care of adult patients with a temporary tracheostomy: standards and guidelines. London: Council of the Intensive Care Society; 2008.

8. Morris LL, Whitmer A, McIntosh E. Tracheostomy care and complications in the intensive care unit. Crit Care Nurse 2013 Oct; 33(5):18-30.

http://dx.doi.org/10.4037/ccn2013518

9. Klompas M, Branson R, Eichenwald EC, Greene LR, Howell
MD, Lee Grace, Magill Shelley S, Maragakis LL, Priebe Gregory P., Speck Kathleen, Yokoe Deborah S and Berenholtz Sean M. Strategies to prevent ventilator-associated pneumonia in acute care hospitals: 2014 Update. Infection Control and Hospital Epidemiology 2014; 35(8): 915-36.

http://dx.doi.org/10.1086/677144

10. Stewart SL, Secrest JA, Norwood BR, Zachary R. A comparison of endotracheal tube cuff pressures using estimation techniques and direct intracuff measurement. American Association of Nurse Anesthetists Journal (AANA J.) 2003 Dec;71(6):443-7.

11. Mitchell RB, Hussey HM, Setzen G. et al. Clinical consensus statement: tracheostomy care. Otolaryngol Head Neck Surg 2013; 148(1):6-20.

http://dx.doi.org/10.1177/0194599812460376

12. Faris C, Koury E, Philpott J, Sharma S, Tolley N, Narula A. Estimation of tracheostomy tube cuff pressure by pilot balloon palpation. J Laryngol Otol 2007 Sep;121(9):869-71.

http://dx.doi.org/10.1017/S0022215107005324

13. Plotnikow GA, Roux N, Feld V. et al. Evaluation of tracheal cuff pressure variation in spontaneously breathing patients. International Journal of Critical Illness and Injury Science 2013;3(4):262-268. http://dx.doi.org/10.4103/2229-5151.124148

14. Valencia M, Ferrer M, Farre R. at al. Automatic control of tracheal tube cuff pressure in ventilated patients in semirecumbent position: A randomized trial. Crit Care Med 2007;35(6):1543-9.

http://dx.doi.org/10.1097/01.CCM.0000266686.95843.7D

15. Standards for the care of adult patients with a temporary tracheostomy : standards and guidelines. Intensive Care Society - ICS - 12 June 2014.

16. Lizy C, Swinnen W, Labeau S, Poelaert J, Vogelaers D, Vandewoude K, Dulhunty J, Blot S. Cuff pressure of endotracheal tubes after changes in body position in critically ill patients treated with mechanical ventilation. Am J Crit Care January 2014; 23(1): e1-e8.

http://dx.doi.org/10.4037/ajcc2014489

17. Motoyama A, Asai S, Konami H. et al. Changes in endotracheal tube cuff pressure in mechanically ventilated adult patients. Journal of Intensive Care 2014; 2(1):7. http://dx.doi.org/10.1186/2052-0492-2-7

18. Lacherade JC, De Jonghe B, Guezennec P. et al. Intermittent subglottic secretion drainage and ventilator-associated pneumonia. Am J Respir Crit Care Med 2010; 182(7):910-7. http://dx.doi.org/10.1164/rccm.200906-08380C

19. Jordan P, Van Rooyen D, Venter D. Endotracheal tube cuff pressure management in adult critical care units. Southern African Journal Of Critical Care 2012; 28(1):15-19. http://dx.doi.org/10.7196/sajcc.129

20. Nseir S, Brisson H, Marquette Ch.-H. A Variations in endotracheal cuff pressure in intubated critically ill patients: prevalence and risk factors. European Journal of Anaesthesiology 
2009;26(3):229-34.

http://dx.doi.org/10.1097/EJA.0b013e3283222b6e

21. Jaber S, Kamel M, Chanques G. Endotracheal tube cuff pressure in intensive care unit: the need for pressure Monitoring. Intensive Care Medicine 2007;33(5):917. http://dx.doi.org/10.1007/s00134-007-0594-2

22. Pelaes de Carvalho T, Spitaletti Araujo NS, Curcio D. et al. Tracheostomized patients care: efficacy of a brief theoretical education program for nursing personnel. Supportive Care in Cancer 2009; 17(6):749-751.

http://dx.doi.org/10.1007/s00520-008-0560-8

23. Rose L, Redl L. Survey of cuff management practices in intensive care units in Australia and New Zealand. Am J Crit Care 2008 Sep;17(5):428-35.

24. Labeu S, Bleiman M, Rello J, Vandijck D, Claes B, Blot S. A knowlende and management of endotracheal tube cuffs: a survey among 591 intensive care nursies. International journal of nursing studies 2015; 52(1):498-499.

http://dx.doi.org/10.1016/j.ijnurstu.2014.09.010

25. Day T, Iles N, Griffiths P. Effect of performance feedback on tracheal suctioning knowledge and skills: randomized controlled trial. J Adv Nurs 2009;65(7):1423-1431.

http://dx.doi.org/10.1111/j.1365-2648.2009.04997.x

\section{NURSES KNOWLEDGE OF TRACHEOSTOMY CUFF CARE BEFORE AND AFTER TRAINING}

S. Kostyliovienė, A. Vaškelytė, D. Grinkevičiūtė

Key words: nurses' knowledge before training, nurses' knowledge after training, tracheostomy tube cuff care.

Summary

Tracheostomy tube cuff care is associated with a high risk of the patient's health, it is important that nurses should have scientific evidence-based knowledge about the cuff care. If the nurses will have the knowledge and good practical skills to supervise quality tracheostomy tube cuff, it will reduce the frequency of adverse events and ensure patient safety.

The aim is to analyze nurses' knowledge of the tracheostomy tube cuff care before and after the training. The study was carried out in 2013 in Kaunas hospital departments in which patients with tracheostomy usually comes from the intensive care unit. The study included 111 nurses. The study was carried out in stages: 1. Nurses questionnaire before training; 2. Nurses' training; 3. Nurses survey after the training. The survey before the training attended by 93 nurses after training - 81. The studies, data collection and evaluation were used in the authors developed "Nurses knowledge's determination".

Results. Most of the nurses said that a special cuff pressure monometer does not measure (before training - 95.2 percent, followed by training - 98.3 percent). Before and after training, almost half of nurses said that never blow air into the tracheostomy cuff (before training - 47.6 percent, followed by training - 45.8 percent). After training significantly more nurses ( 44.4 percent) indicated that the air from the tracheostomy cuff spends every three - four hours. Before training as did 20.1 percent of respondents $\left(\chi^{2}=12.162\right.$, df $=1, p=0.007)$. Before training for 60.9 percent of nurses indicated that the whole do not discharge air from the tracheostomy cuff, after training as claimed 40.3 percent of nurses $\left(\chi^{2}=12.162, \mathrm{df}=1, \mathrm{p}\right.$ $=0.007)$. After teaching at 50.6 percent of nurses indicated that the cuff pressure should be less than $20 \mathrm{cmH} 2 \mathrm{O}$ before training the pressure indicated 3.6 percent of respondents $\left(\chi^{2}=59.048\right.$, df $=3, \mathrm{p}<0.001)$. After teaching at 21.0 percent of nurses said that the tracheostomy cuff pressure is not important, it is important that it would be much exaggerated, before training as claimed 65.5 percent of the surveyed nurses $\left(\chi^{2}=59.048, \mathrm{df}=3, \mathrm{p}<0.001\right)$. The majority (79.6 percent) of nurses, after the training said that the release of air from the tracheostomy cuff suck secretions from the mouth and nasopharynx, before training as did 51.7 percent of respondents $\left(\chi^{2}=9.007, \mathrm{df}=1, \mathrm{p}=0.003\right)$.

Conclusions. After training the greater part of the nurses correctly pointed that the air from the tracheostomy cuff is released every three - four hours, and the cuff pressure must not be less than $20 \mathrm{cmH} 2 \mathrm{O}$. A significantly higher proportion of nurses after the training said that the release of air from the tracheostomy tube cuff suck secretions from the mouth and nasopharynx. Before and after training the majority of respondents said that a special cuff pressure manometer does not measure, and the air in the cuff by the pressure gauge readings inflate only a small part of the nurses.

Correspondence to: alina.vask@gmail.com

Gauta 2016-09-10-11 